\title{
Assessing the Effectiveness of Management Consultancy in Operations of Construction Firms: A Case of Willy Enterprises Ltd in Arusha Tanzania
}

\author{
Mbonde Anthony Jokakuu
}

Department of Accounting and Finance, School of Business Studies and Economics, University of Dodoma, Dodoma - Tanzania

Email:anthonymbonde2015@gmail.com

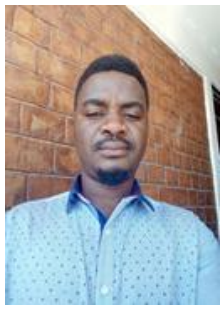

W) Check for updates

\begin{abstract}
This study assessed the Effectiveness of Management Consultancy in Operations of Construction Firms with reference to Willy Enterprises Ltd in Arusha Tanzania. The researcher employed descriptive research design of cross-sectional survey. In this research two objectives were studied: to investigate the knowledge, understanding and perception about Management Consultancy usage in the organization and compare the non-financial operations of the organization before and after engaging Management Consultants. The data were collected in 2012 by way of questionnaires, interviews and documentary analysis. The sample of the participants was fortyfive (45) respondents from the different managerial position of the company and its client-firms. The findings here are part of Master Dissertation on Contribution of Management Consultancy towards Organizational Performance: A Case of Willy Enterprises Ltd in Arusha Tanzania.
\end{abstract}

Keywords: Management consultancy, Operations, Construction firms, Business organization.

JEL Classification: Do2; M10.

\section{Introduction}

Management consultancy is an exciting profession that can offer a great varieties and intellectual challenges for the consultant, whilst also making a very positive impact on the clients and society as a whole (Block and Markowitz, 2000).

The evidence shows that, most of the construction companies which are doing great in the business worldwide are those which use Management Consultancy Services e.g. VINCI is ranked number one construction company of France and the world since 1999, followed by ACS-Spain. Then, BECHTEL - is among the most respected engineering, procurement, and construction companies in the world. Also, HOCHTIEF is ranked number one construction company in German. Others are STRABAG-Austria, SKANSKA-Sweden, KAJIMA-Japan, SAIPEMItaly and ODEBRECHT-Brazil ${ }^{1}$. All of them prove to use Management Consultancy Services in their operations.

Also there is evidence that most of the construction companies which are doing great in Africa are those which use Management Consultancy Services in its operations. Examples, AVENG Group is ranked number one construction company in South Africa, ORASCOM-Egypt, and JULIUS BERGER-Nigeria².

Furthermore, Management Consultancy has the great role to play in Tanzania organizational operations e.g. in transport, insurance, in building and construction companies ${ }^{3}$. But this is not the case with all business organizations in the country because there are a great number of business firms which neither knows the importance of Management Consultancy Services nor using it. This is actually the case with construction sector and occasionally Willy Enterprises Ltd.

Since 1999 the company emerged in the construction industry, up to this moment it has been leading with remarkable projects in the country. The company saves many areas including civil works, building works, production and hiring of hydra form blocks, hiring of earth moving equipment as well as selling various roofing sheets, while recently being one of the major agent of ALAF 4 
As the company continued to expand one year after another, management fails to cope with that situation. The reason is not definite also the general understanding and perception of people working in management about Management Consultancy is not clearly understood.

\section{Purpose of the Study}

Generally, this research intends to assess the Effectiveness of Management Consultancy in Operations of Construction Firms: a case of Willy Enterprises Ltd in Arusha Tanzania.

Specifically intends to:

i. Investigate the knowledge, understanding and perception about Management Consultancy usage in the organization.

ii. Compare the non-financial operations of the organization before and after engaging Management Consultants.

\section{Related Literature}

According to International Council of Management Consultancy Institute ICMCI (2009)

Management Consultancy is the provision of the independent advice and assistance about the process of management to clients with management responsibilities.

While, Management consultant is a professional who, for a fee helps the management of the client organizations define and achieve their goals through improved utilization of resources (Kubr, 1986).

Then, Mantel et al. (2005) define consulting as any form of providing help on the content, process, or structure and series of tasks, where the consultant is not actually responsible for doing the job itself but is helping those who are.

In pursuing the generic purposes of providing professional advice to different organizations, consultancy can intervene in many different ways. Both clients and consultants can choose among so many alternatives that are trying to give an exhaustive and complete picture of these alternatives would be, Block and Markowitz (2000). However, most of the consulting assistance to management will be given in one or more of the following ways or principles:

Providing information; complete and more relevant information is often the main or only thing that client need to make the right decision. It may be information on markets, customers, sector trends, raw materials, suppliers, competitors, potential partners, sources of engineering expertise, government policies and regulations, or others (Greiner and Metzger, 2003).

Providing Specialist Resources; a consultant can be used to supplement the client organization's staff. Usually such consultants will be specialists in areas where the client is looking for short-term expertise or wants to avoid recruiting a new employee (Block and Markowitz, 2000).

Establishing business contacts and linkages; many clients turn to consultants in their search for new business contacts, agents, representative, suppliers, subcontractors, joint-venture and merger partners (Sugata and Daryl, 2002).

Provide expert opinion; various activities fall under this heading. The consultant may be approached to provide expert opinion in cases where the client can choose among several alternative and seek impartial and independent third-party advice before taking the decision. Consultant may be invited to act as an expert witness (testifying expert) in lawsuits or arbitrations calling for specialized knowledge (Naficy, 1997).

Doing diagnostic work; diagnostic skills and instruments are among the consultant's principal assets. Clients use consultants for a wide range of diagnostic chore concerning the organization's strength and weaknesses, positive and negative trends, potential for improvement, barrier to change, competitive position, underutilized resources, technical or human problems requiring management's attention and so on Drucker (1979).

Developing Action Proposals; the consultants may be asked to do the whole job, share the task with the client, or act as an adviser to a client who has chosen to develop new proposals with his or her own resources (Stroh and Johnson, 2006).

Counseling and coaching; Management consultants can render excellent service to managers and entrepreneurs who need strictly personal feedback and relaxed friendly advice on their leadership style, behavior, work habits, relation with colleagues, and weaknesses that could be damaging to the business (Mantel et al., 2005).

All referred related literature shows that if the firm wants to grow and have best organizational operations, they have to engage fully in using management consulting services. Many of Tanzania Construction companies are still growing slowly, some fail to face strong competitions as far as foreign organizations are concerned. Therefore, this study intended to bring full attention and understanding as well as usage of management consultancy and the benefits they can offer.

\section{Research Methodology}

This study used a cross sectional survey approach. The population proposed was the employees of Willy Enterprises Ltd and its client-firms in Arusha Tanzania by 2012. The study had a sample size of forty-five (45) respondents from different managerial posts of the company and the company's financial reports for twelve (12) years from 1999. The study used both primary and secondary data. Primary data employed interviews and questionnaires.

Furthermore, secondary data were from the accounting department and management department by reviewing the records and documents such as financial statements and reports by different consultants in the company. Also, some data were analyzed using Microsoft Excel for tables. 


\section{Findings and Discussion}

Presentation and discussion of the findings drew upon two research questions:

i. What is the extent of knowledge and understanding of Management Consultancy by managers in the organization?

ii. Is there any difference in the Non-financial operations of the organization before and after engaging Management Consultants?

\section{The Knowledge, Understanding and Perception about Management Consultancy Usage in the Firm}

In this context the study wanted to know the reasons behind the mentioned factors on how they affect Management Consultancy usage in Tanzania organizations. Six primary factors were discussed on how they affect Management Consultancy usage.

These factors are as follows; the primary sources of knowledge about Management Consultancy, Awareness of the managers on the importance of Management Consultancy, Perception on Expenses and Immaturity, Size of the firm and Complexity of Management Consultancy.

To study the effectiveness of these factors, a likert scale was drawn with the answers "Strongly agree", "Agree", "Not agree Not disagree", "Disagree" and "Strongly Disagree" with exception of the first factor only. From the responses that were obtained from twenty two (22) respondents, the analysis was done. The results on the influence of these eight primary factors on Management Consultancy usage and the interpretations are found in the specific sub-sections here-under.

\subsection{Primary Source of Knowledge about Management Consultancy}

The respondents were asked to state if they know anything about Management Consultancy, all respondents said "YES", and then, were inquired to give their primary source of knowledge about Management Consultancy. Among thirty two respondents, twenty five $78.13 \%$ said their primary source is from College or University education, $15.62 \%$ got knowledge from short training courses at working place and $6.25 \%$ from personal efforts i.e. reading books, journals, newspapers, magazines, surfing and sharing ideas with friends. Also, $6.25 \%$ of the respondents from Kasegenya, 6.25\% from Mawenzi, 9.37\% from Security Group and 9.38\% from Tan Auditors, all got knowledge from College or University. This shows most of the employees who are holding managerial positions in the company are competent and well trained as far as Management Consultancy is concerned. Table 1 summarizes the source of knowledge about Management Consultancy to the respondents.

Table-1. Cross - Tabulation of the Source of Knowledge about Management Consultancy and Composition of the Respondents

\begin{tabular}{|c|c|c|c|c|c|c|}
\hline & & \multicolumn{3}{|c|}{ Source of Knowledge } & \multirow[b]{2}{*}{ Total } & \multirow[b]{2}{*}{ Percentage } \\
\hline & & $\begin{array}{l}\text { Collage/ } \\
\text { University }\end{array}$ & $\begin{array}{l}\text { Short } \\
\text { training }\end{array}$ & $\begin{array}{l}\text { Personal } \\
\text { efforts }\end{array}$ & & \\
\hline \multirow{5}{*}{$\begin{array}{l}\text { Companies } \\
\text { with } \\
\text { Respondents }\end{array}$} & Willy \&Co & 15 & 5 & 2 & 22 & $68.75 \%$ \\
\hline & Tan Auditors & 3 & O & $\mathrm{O}$ & 3 & $9.38 \%$ \\
\hline & Kasegenya & 2 & O & $\mathrm{O}$ & 2 & $6.25 \%$ \\
\hline & Mawenzi & 2 & O & $\mathrm{O}$ & 2 & $6.25 \%$ \\
\hline & Security Group & 3 & 0 & $\mathrm{O}$ & 3 & $9.37 \%$ \\
\hline \multicolumn{2}{|l|}{ Total } & 25 & 5 & 2 & 32 & - \\
\hline \multicolumn{2}{|l|}{ Percentage } & $78.13 \%$ & $15.62 \%$ & $6.25 \%$ & - & $100 \%$ \\
\hline
\end{tabular}

\subsection{Awareness of the Managers on the Importance of Management Consultancy}

From the responses that were obtained from twenty two (22) respondents as shown in Table 2; 36.36\% of the respondents, agreed that managers don't know the importance of Management Consultancy Services to their companies, $27.27 \%$ strongly agreed, $18.18 \%$ disagreed and $9.09 \%$ were neutral. The results showed the weighted average of 3.55 (4) which fall under the category of disagree. Therefore, the general perception of all the respondents is that the managers know the importance of Management Consultancy Services to their organizations. Table 2 summarizes the respondents' perception on awareness of the managers on the importance of Management Consultancy.

Table-2. Perception on Managers' Awareness on the Importance of Management Consultancy

\begin{tabular}{|c|c|c|c|c|c|}
\hline $\begin{array}{lllr}\text { Managers don't know the } \\
\text { importance } & \begin{array}{l}\text { of } \\
\text { Management }\end{array} \\
\text { Consultancy } & \text { Services to their } \\
\text { firms } & & \end{array}$ & $\begin{array}{l}\text { Number of } \\
\text { Respondents }\end{array}$ & Percentage & $\begin{array}{l}\text { Likert Scale } \\
\text { Weights }\end{array}$ & $\begin{array}{l}\text { Weighte } \\
\text { d Totals }\end{array}$ & $\begin{array}{l}\text { Weighted } \\
\text { Average or } \\
\text { Mean }\end{array}$ \\
\hline Strongly Agree & 6 & $27.27 \%$ & 5 & 30 & \multirow{6}{*}{3.55} \\
\hline Agree & 8 & $36.36 \%$ & 4 & 32 & \\
\hline Neutral & 2 & $9.09 \%$ & 3 & 6 & \\
\hline Disagree & 4 & $18.18 \%$ & 2 & 8 & \\
\hline Strongly Disagree & 2 & $9.09 \%$ & 1 & 2 & \\
\hline Total & 22 & $100 \%$ & 15 & 78 & \\
\hline
\end{tabular}


6.3. Perception on Expenses (is Management Consultancy Very Expensive or Not?)

The study on impacts of this factor on Management Consultancy usage was drawn as shown in the Table 3

Table-3. Perception on Expenses Incurred on Hiring Management Consultancy

\begin{tabular}{l|l|l|l|l|l}
\hline $\begin{array}{l}\text { Management Consultancy is very } \\
\text { Expensive for Tanzanian firms }\end{array}$ & $\begin{array}{l}\text { Number of } \\
\text { Respondents }\end{array}$ & Percentage & $\begin{array}{l}\text { Likert Scale } \\
\text { Weights }\end{array}$ & $\begin{array}{l}\text { Weighted } \\
\text { Totals }\end{array}$ & $\begin{array}{l}\text { Weighted } \\
\text { Average or Mean }\end{array}$ \\
\hline Strongly Agree & 10 & $45.45 \%$ & 5 & 50 & \\
\hline Agree & 5 & $22.72 \%$ & 4 & 20 & \\
\hline Neutral & 3 & $13.64 \%$ & 3 & 9 & 3.91 \\
\hline Disagree & 3 & $13.63 \%$ & 2 & 6 & \\
\hline Strongly Disagree & 1 & $4.54 \%$ & 1 & 1 & \\
\hline Total & $\mathbf{2 2}$ & $\mathbf{1 0 0 \%}$ & $\mathbf{1 5}$ & $\mathbf{8 6}$ & \\
\hline Source: Fieldwork Data, 2012 & &
\end{tabular}

Source: Fieldwork Data, 2012

From the responses that were obtained from twenty two (22) respondents as shown from Table 3 above; $45.45 \%$ of the respondents, strongly agreed that Management Consultancy Service is very expensive for Tanzania Organizations, $22.72 \%$ agreed, $13.64 \%$ were neutral, $13.64 \%$ disagreed and 4.54\% strongly disagreed. By applying Likert Scale Weighing, the weighted mean was 3.91 approximate to 4 . The general opinion of the respondents agreed that Management Consultancy is very expensive for Tanzanian organizations. Example, in the year 2009, Willy Enterprises Ltd paid 1,074,122 Tshs to Tan-Auditors for Accounting and Auditing fees and 1,245,982 Tshs for 2010 respectively (company financial statements 2010).

But this is not the case with Management Consultancy firms (Service providers). On the interview with one of the respondents from Mawenzi Insurance Brokers Ltd, the following interesting explanation was given:

"Many of Tanzania organizations fear to take risk of using our services thinking that it's very expensive, that is not true for the one who is capable of weighing the positive impacts to the organization as compared with little amount of charge they pay as per single service provided. Example, Willy Enterprise Ltd was not aware that the kind of business activity they are doing is very risky as they deal with drilling works, civil works, hiring of their vehicles for mining services (bauxite mining), of which its very dangerous to operate without being insured. So now our customer can operate in a safe environment as they are fully secured by us".

Therefore Business companies need to be educated on the fact that they should not fear to take risk of using Management Consultancy Services, rather they should weigh the positive outcomes to their organizations as compared to the amount of charges paid by them.

\subsection{Immaturity of the Organizations}

The study on perception of this factor on Management Consultancy usage was drawn as shown in the Table 4.

From the responses that were obtained from twenty two (22) respondents; 14.63.63\%) of the respondents, disagreed that Tanzania business organizations are too immature to use management consultancy services, 3(13.63\%) were neutral and 3(13.64\%) strongly agreed. By applying Likert Scale Weighing, the weighted mean was 2.45 approximate to 3.

The general opinion of the respondents was neutral, means Tanzania business organizations are too immature to use management consultancy services. But if you judge by using the percentage, the results showed that $72.72 \%$ (63.63\% plus $9.09 \%)$ of the respondents disagree that Tanzania business organizations are too immature to use Management Consultancy Services, this imply that Management Consultancy is of significant importance towards organization growth rather than saying we are not matured enough to use these services. Table 4 summarizes the respondents' perception on Immaturity of Tanzania Organizations towards usage of Management Consultancy services.

Table-4. Perception on Immaturity of the Organization towards Usage of Management Consultancy Services

\begin{tabular}{l|l|l|l|l|l}
\hline $\begin{array}{l}\text { Tanzania businesses are too } \\
\text { immature to use management } \\
\text { consultancy services }\end{array}$ & $\begin{array}{l}\text { Number of } \\
\text { Respondents }\end{array}$ & Percentage & $\begin{array}{l}\text { Likert Scale } \\
\text { Weights }\end{array}$ & $\begin{array}{l}\text { Weighted } \\
\text { Totals }\end{array}$ & $\begin{array}{l}\text { Weighted } \\
\text { Average } \\
\text { Mean }\end{array}$ \\
\hline Strongly Agree & 3 & $13.64 \%$ & 5 & 15 & \\
\hline Agree & 0 & 0 & 4 & 0 & \\
\hline Neutral & 3 & $13.63 \%$ & 3 & 9 & 2.45 \\
\hline Disagree & 14 & $63.63 \%$ & 2 & 28 & \\
\hline Strongly Disagree & 2 & $9.09 \%$ & 1 & $\mathbf{5 4}$ & \\
\hline Total & $\mathbf{2 2}$ & $\mathbf{1 0 0 \%}$ & $\mathbf{1 5}$ & $\mathbf{5 4}$ \\
\hline Source: Fieldwork Survey, 2012 & & &
\end{tabular}

6.5. Size of the Firm

The study on perception of this factor on Management Consultancy usage was drawn as shown in the Table 5 .

Table-5. Perception on how size of the Firm affects Management Consultancy usage.

\begin{tabular}{l|l|l|l|l|l}
\hline $\begin{array}{l}\text { Only large firms have a } \\
\text { reason to use consulting } \\
\text { services }\end{array}$ & $\begin{array}{l}\text { Number of } \\
\text { Respondents }\end{array}$ & Percentage & $\begin{array}{l}\text { Likert Scale } \\
\text { Weights }\end{array}$ & $\begin{array}{l}\text { Weighted } \\
\text { Totals }\end{array}$ & $\begin{array}{l}\text { Weighted } \\
\text { Average or Mean }\end{array}$ \\
\hline Strongly Agree & 1 & $4.55 \%$ & 5 & 5 & \\
\hline Agree & 2 & $9.09 \%$ & 4 & 8 & \\
\hline Neutral & 4 & $18.18 \%$ & 3 & 12 & 1.55 \\
\hline Disagree & 6 & $27.27 \%$ & 2 & 12 & \\
\hline Strongly Disagree & 9 & $40.90 \%$ & 1 & 9 & \\
\hline Total & $\mathbf{2 2}$ & $\mathbf{1 0 0} \%$ & $\mathbf{1 5}$ & $\mathbf{3 4}$ & \\
\hline Source: Fieldwork Survey, 010 & & &
\end{tabular}

Source: Fieldwork Survey, 2012 
From the responses that were obtained from twenty two (22) respondents as shown from Table 5 above; $9(40.90 \%)$ of the respondents, strongly disagreed that only large organizations have a reason to use Management Consultancy Service, 6(27.27\%) disagreed, 4(18.18\%) were neutral, 2(9.09\%) agreed and $1(4.55 \%)$ strongly agreed. By applying Likert Scale Weighing, the weighted mean was 1.55 which is 2 .

The general opinion of the respondents agreed that only large organizations have a reason to use management consultancy services. This gives the implication that size of the organization affects the use of Management Consultancy in the organization.

\subsection{Complexity of Management Consultancy}

The study on perception of this factor was drawn as shown in the Table 6 below.

Table-6. Perception on Complexity of Hiring Management Consultancy Services

\begin{tabular}{l|l|l|l|l|l|}
\hline $\begin{array}{l}\text { Management Consultancy Services } \\
\text { make business more complicated }\end{array}$ & $\begin{array}{l}\text { Number of } \\
\text { Respondents }\end{array}$ & Percentage & $\begin{array}{l}\text { Likert Scale } \\
\text { Weights }\end{array}$ & $\begin{array}{l}\text { Weighte } \\
\text { d Totals }\end{array}$ & $\begin{array}{l}\text { Weighted } \\
\text { Average or } \\
\text { Mean }\end{array}$ \\
\hline Strongly Agree & 1 & $4.55 \%$ & 5 & 5 & \\
\hline Agree & 2 & $9.09 \%$ & 4 & 8 & 2.32 \\
\hline Neutral & 3 & $13.63 \%$ & 3 & 26 \\
\hline Disagree & 13 & $59.09 \%$ & 2 & 3 & \\
\hline Strongly Disagree & 3 & $13.63 \%$ & 1 & $\mathbf{5 1}$ \\
\hline Total & $\mathbf{2 2}$ & $\mathbf{1 0 0 \%}$ & $\mathbf{1 5}$ & \\
\hline
\end{tabular}

Source: Fieldwork Survey, 2012

From the responses that were obtained from twenty two (22) respondents as shown from Table 6 above; $13(59.09 \%)$ of the respondents, disagreed that Management Consultancy Service make business more complicated, $3(13.63 \%)$ were neutral and 3(13.64\%) strongly disagreed. By applying Likert Scale Weighing, the weighted mean was 2.32 approximate to 2.

The general opinion of the respondents agreed that management consultancy services make business more complicated. This implies that there is a need to enlighten managers on the importance of management consultancy services rather than believing that it makes their business more complicated.

\section{Comparison of the Non-Financial Operations of the Firm before and After} Engaging Management Consultants

All questionnaires filled by managers of the firm give evidence on the usage of Management Consultancy Services and they started to use by the year 2006. Therefore, before engaging refers to a period from 1999 to 2005 and after engaging is from 2006 to 2010 . Five areas of operations were to be studied on whether they affect Management Consultancy usage as discussed here-under.

\subsection{Human Resources (Quality of Employees)}

The respondents were asked to give details on types or categories of Management Consultancy Services that are used by Willy Enterprises Ltd. Among the services that seemed to be mostly used by the company were on the area of Human Resources Management.

The company was advised to improve the quality of employees they enroll and also develop the existing one by conducting various training and workshops within the organization. Example, in 2008 Tan Auditors conducted a seminar with finance and auditing department to advice the departmental members on how to improve accuracy in financial record keeping so as to avoid errors and fraud in the company's financial statements (Annual Report, Willy Enterprises Ltd, 2008).

With that advice, the company employed highly qualified workers as evidenced by $65.62 \%$ of all respondents have Bachelor degree, and then 12.5\% have Advanced degree or profession as indicated in Table 7 below. This gives the implication that before introduction of Management Consultancy the firm was just employing unqualified workers but after the adoption of Management Consultancy it started employing quality staff or developing the existing ones.

Table-7. Cross Tabulation of the Respondent's Education Level versus Working Experience with Business Enterprise (s)

\begin{tabular}{|c|c|c|c|c|c|c|}
\hline & & \multicolumn{3}{|c|}{ Educational level } & \multirow[b]{2}{*}{ Total } & \multirow[b]{2}{*}{ Percentage } \\
\hline & & $\begin{array}{l}\text { Advanced } \\
\text { Diploma }\end{array}$ & $\begin{array}{l}\text { Bachelor } \\
\text { Degree }\end{array}$ & $\begin{array}{l}\text { Advanced } \\
\text { degree/profession } \\
\text { (Masters/PGD, } \\
\text { PhD, CPA, etc) }\end{array}$ & & \\
\hline \multirow{4}{*}{$\begin{array}{l}\text { Working experience with } \\
\text { Business enterprises }\end{array}$} & Less than 1 year & 1 & 3 & $\mathrm{O}$ & 4 & $12.5 \%$ \\
\hline & $1-2$ years & 3 & 7 & $\mathrm{O}$ & 10 & $31.25 \%$ \\
\hline & $3-5$ years & 1 & 9 & 1 & 11 & $34.38 \%$ \\
\hline & $6-10$ years & 2 & 2 & 3 & 7 & $21.87 \%$ \\
\hline \multicolumn{2}{|l|}{ Total } & 7 & 21 & 4 & 32 & - \\
\hline \multicolumn{2}{|l|}{ Percentage } & $21.88 \%$ & $65.62 \%$ & $12.5 \%$ & - & $100 \%$ \\
\hline
\end{tabular}




\subsection{Technology}

Another area that Willy Enterprises Ltd seemed to be user-friend of Management Consultancy services is on Information Technology.

On the interview done with a General Manager, the study found out that in the year 2007 the company established its own website (www.willy.co.tz), then the next question to the General Manager was where he got an idea of establishing a website? The response was as follows:

"We were advised by one of our consultant that if we want to enlarge our market share, we must have a website for easily advertisement of our products, since early 2000, our company emerged in the construction industry and up to this moment we have been leading with remarkable projects in the country. Our company serves many areas including civil works, building works, production and hiring of hydra form blocks, hiring of earth moving equipment as well as selling roofing sheets, therefore, by advertising through our website we can achieve everything".

The evidence above is enough to say that Management Consultancy contributed towards technological advancement in the company which was not there before its introduction.

Apart from that, many things in the company have been computerized since 2006, for example, on the way accounting records are prepared. Before 2006 they were using manual system, but in 2006 the company employed an IT specialist as a result of the advice given by a consultant (Tan Auditors), and the company started to use computerized system in keeping its books of accounts (Field Data, 2012)

\subsection{Legal Aspects}

On the interview done to the Branch Manager, the study found out that, before establishment of Management Consultancy, the company encountered so many legal cases e.g. tax avoidance, but after establishment of Management Consultancy the company managed to minimize legal cases, as for any legal matter they usually face their consultants for professional advice.

\subsection{Taxation}

This is another area of which Management Consultancy brought changes in the company after its establishment.

For example, Willy Enterprises Ltd was not aware on how to use tax loopholes i.e. tax exemptions, so as to minimize the burden of tax to be paid to save unnecessary expenses, then after starting to use Management Consultancy Services, Company profits increased one year after another (Willy Enterprises Ltd. Audited Financial Statements, 2010).

\subsection{Quality of the Service Offered}

On the interview done with the Branch Manager, the study found out that, after they understood the importance of Management Consultancy, they decided to conduct one seminar at the end of every three month to all staff to educate them on customer care (to take their customers as a valuable item for their prosperity).

She said that they usually invited an expert from outside to conduct that seminar; this enabled the company to improve quality of the services that they offered to the public day after day.

\section{Conclusion}

This paper was able to make distinct investigation about the effectiveness of management consultancy in operations of construction firms.

It is quite clear that Organizational performance depends on many factors including usage of management consultants' services for their promptly expansion.

The government should put extraneous efforts to advocate the Consulting field in the country like enactment of Policies and Establishment of Regulatory Body.

Therefore, the study saw a need for formational as well as institutional reforms to benefit fully from Management Consultancy Services, and avail Tanzania economy all together.

\section{References}

Block, P. and A. Markowitz, 2000. The flawless consulting fieldbook and companion: A guide to understanding your expertise. 1st Edn., New York: John Wiley \& Sons, Inc. pp: 2-65.

Drucker, P.F., 1979. Why management consultants? In the evolving science of management Edited by Z. Melvin and R. Greenwood. New York: Amacom Frank.

Greiner, L. and R. Metzger, 2003. Consulting to management. Englewood Cliffs, N.J: Prentice Hall.

Kubr, M., 1986. Management consulting: A guide to the profession. 2nd Edn., Geneva: Bookwell Publications. ILO. pp: 44-50.

Mantel, S.R.J., J.R. Meredith, S.M. Shafer and M.M. Sutton, 2005. Core concepts: Project management practice. 2nd Edn., New York: Willey.

Naficy, M., 1997. The fast track: The insider's guide to winning jobs in the management consulting, investment banking and securities trading. 1st Edn., New York: Crown Business. pp: 93-103.

Stroh, L.K. and H.H. Johnson, 2006. The basic principles of effective consulting. Mahwah: Lawrence Erlbaum Associates.

Sugata, B. and T. Daryl, 2002. Management consulting: A complete guide to the industry. 2nd Edn., New York: John Wiley \& Sons, Inc.

Willy Enterprises Ltd. Audited Financial Statements, 2010. Company Publication. Arusha, Tanzania. Available from www.willy.co.tz [Accessed 21/10/2011].

http://villageearth.org/ visited on $21 / 10 / 2011$

http://www.cgmcintire.com/2011/05/importance-of-sales-management.html visited on 21/10/2011

http://www.methodframeworks.com/consulting/corporate/corporate-strategic-planning/index.html visited on $\underline{21 / 10 / 2011}$

http://blog.royaltyuniverse.com/top-10-reasons-why-to-choose-management-consulting visited on $21 / 10 / 2011$

http://www.timegenie.com cited on $19^{\text {th }}$ February, 2012

http:/ / www.tpsftz.Org - cited on $19^{\text {th }}$ February, 2012

http:// www.tpsftz.org - cited on $19^{\text {th }}$ February, 2012 
http://www.arushamunicipal.go.tz - cited on $19^{\text {th }}$ February, 2012

http://www.unwto.org/facts/eng/pdf/barometer/UNWTO Barom10_update august_en.pdf. Retrieved 2011-11-17.

http//www.africapoint.com, retrieved on $10^{\text {th }}$ February 2012

http//www.linkelin.com, retrieved on $29^{\text {th }}$ December 2011

http://www.businessdictionary.com accessed on 23/08/2012

www.willy.co.tz retrieved on $26^{\text {th }}$ august 2012

Citation | Mbonde Anthony Jokakuu (2018). Assessing the Effectiveness of Management Consultancy in Operations of Construction Firms: A Case of Willy Enterprises Ltd in Arusha Tanzania. Asian Business Research Journal, 3: 26-32. History:

History:

Revised: 31 August 2018

Accepted: 4. October 2018

Published: 6 November 2018

Licensed: This work is licensed under a Creative Commons

Attribution 3.0 License (cc)

Publisher: Eastern Centre of Science and Education

Eastern Centre of Science and Education is not responsible or answerable for any loss, damage or liability, etc. caused in relation to/arising out of the use

of the content. Any queries should be directed to the corresponding author of the article.
The recific financial support.

Competing Interests: The author declares that there are no conflicts of interests regarding the publication of this paper.

Transparency: The author confirms that the manuscript is an honest features of the study have been omitted; and that any discrepancies from the study as planned have been explained.

Ethical: This study follows all ethical practices during writing. accurate, and transparent account of the study was reported; that no vital 